\title{
3D Clinorotation Affects Drug Sensitivity of Human Ovarian Cancer Cells
}

\author{
Dawid Przystupski ${ }^{1,2}$ - Agata Górska ${ }^{2,3} \cdot$ Anna Szewczyk $^{2,4} \cdot$ Małgorzata Drąg-Zalesińska $^{5} \cdot$ Julita Kulbacka $^{2}$
}

Received: 15 March 2020 / Accepted: 5 April 2021 / Published online: 3 June 2021

(c) The Author(s) 2021

\begin{abstract}
Numerous studies have reported that gravity alteration displays a remarkable influence on the biological processes of cancer cells. Therefore, gravity-related experiments have become a promising method of improving knowledge in the field of cancer biology and may be useful to detect remarkable implications for future cancer treatment. Taking this concept further, we used a 3D clinostat (3D-C; $10 \mathrm{rpm}$ of changing direction) to analyse the effect of short-term exposure to simulated microgravity $(s \mu g)$ on cisplatin sensitivity of drug resistant human ovarian cancer cells SKOV-3. This allowed us to investigate whether altered gravity affects drug susceptibility of cancer cells. Our studies revealed that $s \mu g$ exposure affects SKOV-3 cells morphology and drug efficiency. We observed the altered cell shape, the presence of membrane blebbing and lamellipodia as well as the lack of filopodia when the cells had been cultured on 3D-C for $2 \mathrm{~h}$. Cytotoxicity, cell death and cell cycle assays showed an increased percentage of apoptotic cells and G0/G1 cell cycle arrest after exposure on the 3D-C with cisplatin in comparison to the static control, non clinorotated cells. Cell proliferation and migration were altered after the exposure to $s \mu g$ as well. Our studies suggest that the altered gravity conditions affected cellular mechanisms involved in cisplatin resistance, resulting in higher sensitivity of cancer cells to the chemotherapeutic. The investigation and clarification of these results may be a crucial step toward improving our understanding of the relationship between cellular resistance to chemotherapy and the response to altered gravitational conditions.
\end{abstract}

Keywords Simulated microgravity $\cdot$ Gravitational stress $\cdot$ Multidrug resistance $\cdot$ Cisplatin $\cdot$ Ovarian cancer $\cdot$ Cell cycle

\section{Introduction}

This article belongs to the Topical Collection: The Effect of Gravity on Physical and Biological Phenomena

Guest Editor: Valentina Shevtsova

Dawid Przystupski

dawid.przystupski@student.umed.wroc.pl

1 Department of Pediatric Bone Marrow Transplantation, Oncology and Hematology, Wroclaw Medical University, Borowska 213, 50-556 Wroclaw, Poland

2 Department of Molecular and Cellular Biology, Wroclaw Medical University, Borowska 211A, 50-556, Wroclaw, Poland

3 Department of Cell Pathology, Faculty of Biotechnology, University of Wroclaw, 50-383 Wroclaw, Poland

4 Department of Animal Developmental Biology, Institute of Experimental Biology, University of Wroclaw, Sienkiewicza 21, 50-357 Wrocław, Poland

5 Department of Human Morphology and Embryology, Division of Histology and Embryology, Wroclaw Medical University, Chalubinskiego 6a, 50-368 Wroclaw, Poland
The last 50 years have witnessed the rapid development of space industry, raising interest in space medicine. Among all the stressors and altered environmental conditions present in space, microgravity is widely considered to be the most important factor influencing the human physiology, therefore generating considerable concern in terms of experiments simulating this condition. Both simulated $(s \mu g)$ and real microgravity $(\mu g)$ have been demonstrated to have influence on numerous cellular processes through dynamic variations in gene expression (Wehland et al. 2015; Xu et al. 2018), projecting on long-term effects expressed in metabolic alterations and autophagy (Arun et al. 2017; Li et al. 2018; Wang et al. 2013), proliferation and differentiation (Arun et al. 2017; Kim et al. 2017; Lei et al. 2018; Sokolovskaya et al. 2014), as well as - eventually - cells' death (Arun et al. 2017; Kang et al. 2011b; Xu et al. 2018). Different approaches exist aiming to simulate microgravity conditions (Brungs et al. 2019; Herranz et al. 2013). We have 
chosen the principle of $3 \mathrm{D}$ clinorotation in the operational rotational velocity of $10 \mathrm{rpm}\left(60^{\circ} / \mathrm{sec}\right)$, because it has been reported in many mammalian cell experiments (Borst and Van Loon 2009) as providing the optimum between shear stress occurrence and alteration of gravity vector (Wuest et al. 2017, 2015).

There is still a considerable uncertainty in regard to the establishment of the exact mechanism of the cellular graviperception (Lambert et al. 2007; Sundaresan et al. 2004). However, a substantial amount of literature indicates the vital role of the cellular cytoskeleton (Xu et al. 2018), along with mechanoreceptors and adhesive molecules (Rudimov and Buravkova 2016) in those processes. An increasing number of studies have described a characteristic morphology change of adherent cells cultured in real and simulated microgravity (Sundaresan et al. 2004) caused by cytoskeletal rearrangements (Corydon et al. 2016; Crawford-Young 2006; Infanger et al. 2006b; Li et al. 2009), therefore influencing the mobility of the cell and postulated changes of cell membrane viscosity (Janmaleki et al. 2016; Li et al. 2009; Nassef et al. 2019). Remarkably, the unique set of physiological alterations caused by the exposure to microgravity overall contributes to an anticancer effect, as reported in various experiments in vitro. Some of the observed effects are indeed associated with the microgravity-induced changes in focal adhesion and cytoskeleton, therefore reducing cancer cell migration and invasion ( $\mathrm{Li}$ et al. 2009; Nassef et al. 2019). Additionally, a growing body of literature has examined the more specific influence of $s \mu g$ and $\mu g$ on cancer cells, such as cell death regulation (Arun et al. 2017; Kossmehl et al. 2003), reduced proliferation and differentiation (Arun et al. 2017; Chang et al. 2013; Chung et al. 2017; Kim et al. 2017; Pisanu et al. 2014; Svejgaard et al. 2015) as well as orchestrated regulation of cellular pathways underlying metastasis (Chang et al. 2013; Ivanova et al. 2018) or cytokine secretion (Ma et al. 2014; Svejgaard et al. 2015). Thus, experiments implementing simulated microgravity have been gaining much more attention as a new tool for the understanding of cancer cell physiology and its potential use for the development of novel therapies for tumor treatment (Chen 2018). Moreover, the alterations of membrane fluidity caused by $\mu g$ are likely to have an impact on pharmacodynamics and drug uptake (Kohn and Hauslage 2019). Only a few studies have addressed the issue of potential multidrug resistance (MDR) phenomena alleviation by $\mu g$ conditions (Piepmeier et al. 1997).

Our knowledge of strategies for increasing the drug sensitivity in ovarian cancer is largely based on severly limited data. Platinum derivatives are currently the firstchoice chemotherapeutics recommended for the treatment of ovarian cancer (Gonzalez-Martin et al. 2013). Cisplatin (cis-diaminadichloroplatinum (II), cDDP) exerts cytotoxic activity mainly through binding to DNA and altering its structure, which blocks the transcription and replication, consequently leading to cellular apoptosis (Ma et al. 2014). However, drug resistance is an important limitation in the clinical use of cDDP. Mechanisms of resistance to cDDP in ovarian cancer are complex and can be divided in two groups: 1) those that limit the formation of cytotoxic platinum-DNA adducts (also through the modulation of drug's efflux and uptake), and 2) those that prevent cell death occurrence after platinum-DNA adduct formation (Basu and Krishnamurthy 2010; Kartalou and Essigmann 2001; Shen et al. 2012; Stewart 2007). SKOV-3 cell line remains the optimal model of MDR in ovarian cancer due to its specific resistance to cDDP. This paper remains an attempt to expand the knowledge in the field of physiology of drug-resistant cancer cells exposed to $s \mu g$, as well as the quest for possible synergy between gravitational stress and drug response in ovarian cancer cells.

\section{Material and Methods}

\section{Cell Culture and Drug}

Human ovarian cancer cells SKOV-3 were collected from the American Type Culture Collection (ATCC, London, UK). Cells were cultured as a monolayer in Dulbecco's modified Eagle medium (DMEM, Sigma-Aldrich, USA) for SKOV-3 cells containing $2 \mathrm{mM}$ L-glutamine, $10 \%$ fetal bovine serum (FBS, Sigma-Aldrich), 20 units penicillin and $20 \mu \mathrm{g}$ streptomycin/mL (Sigma-Aldrich) at $37{ }^{\circ} \mathrm{C}$ in a humidified incubator with $5 \% \mathrm{CO}_{2}$. For the experiments, the cells were washed with Dulbecco's Phosphate Buffered Saline (PBS, Bioshop, UK) and detached from the surface of the flask using $0.25 \%$ trypsin with $0.02 \%$ EDTA (SigmaAldrich, Poland). To investigate the effect of cytostatic drug on SKOV-3 cells under simulated microgravity we used cis-diamineplatinum (II) dichloride (cDDP, Sigma, Cat. no. 479306) which was dissolved in the PBS buffer to the concentration of $5 \mathrm{mM}$ and then diluted with culture medium to a final concertation of $25 \mu \mathrm{M}$.

\section{Experimental Protocol}

To examine the effect of simulated microgravity $(s \mu m)$ on human ovarian cancer cells, a 3D clinostat (3D-C) was developed by engineers from Wroclaw University of Science and Technology. The samples in 3-D clinostat were rotated along two independent axes to change their orientations at constant speeds and directions relative to the gravity vector, thereby eliminating the effect of gravity (Chen et al. 2019).

Base, outer and inner parts are made of an aluminium rectangular-shape profiles that have holes made by $\mathrm{CNC}$ machine. The main bracket is made of a stainless-steel 
plate, which has laser cut holes. Bracket, outer and inner part are connected by aluminium pipes in which the electrical wires were routed. The outer and inner part rotates independently in clock or clockwise direction. Two step motors are responsible for rotational movement with available speed from $0.1 \mathrm{rpm}$ to $60 \mathrm{rpm}$. Motors are controlled by step motor controller DRV8835 build on microcontroller. User can switch rotational speed with knob. Rotating elements have been balanced to avoid vibrations. The rotation speed was set at $10 \mathrm{rpm}\left(60^{\circ} / \mathrm{sec} ; 1,05 \mathrm{rad} / \mathrm{sec}\right.$; the residual acceleration amounts to app. $0,032 \mathrm{~m} / \mathrm{s}^{2}$ ) and only the cells located within the central area of $3 \mathrm{~cm}$ radius were included in the experiments. For $s \mu m$ experiments, $3 \times 10^{4} \mathrm{SKOV}-3$ cells $/ \mathrm{cm}^{2}$ were plated on a $35 \mathrm{~mm}$ Petri dish. After $24 \mathrm{~h}$, the dishes were fully filled with growth medium and carefully covered with parafilm without leaving any air bubbles beneath it. Directly before clinorotation, half of the samples were filled with culture medium supplemented with $25 \mu \mathrm{M}$ cisplatin. Additionally, cells $\left(3 \times 10^{4}\right.$ cells $\left./ \mathrm{cm}^{2}\right)$ were seeded in a $35 \mathrm{~mm}$ imaging dish ( $\mu$-Dish $35 \mathrm{~mm}$, Ibidi, Germany) and fixed for morphology and cytoskeleton analyses immediately after the experiment. The exposure time in $s \mu m$ was $2 \mathrm{~h}$. The dishes were fixed on the clinostat in an incubator at $37^{\circ} \mathrm{C}$. The control group $(1 \mathrm{~g})$ was prepared in the same way and located close to rotating 3D-C. After the experiment, the cells were rinsed with PBS three times and detached from Petri dishes using $0.25 \%$ trypsin with $0.02 \%$ EDTA and processed for further analyses in cisplatin-free medium. For MTT and SRB assays, the cells were seeded on 96-well plates $\left(3 \times 10^{4}\right.$ cells $\left./ \mathrm{cm}^{2}\right)$ and incubated for 24 or $72 \mathrm{~h}$. Additionally, the cells were plated on 6-well plates and incubated for 24 and $72 \mathrm{~h}$ to carry out cell death and cell cycle assays (cell density seeding $3 \times 10^{4}$ cells $/ \mathrm{cm}^{2}$ ) and for 7 days to carry out clonogenic assay (cell density seeding 15 cells $/ \mathrm{cm}^{2}$ ). To analyze whether exposure to $s \mu m$ affected the migration of SKOV-3 cells, the cells were seeded in Boyden chambers (cell density seeding $2 \times 10^{3}$ cells/insert) for 24 and $72 \mathrm{~h}$, as described below.

\section{SRB Assay}

Sulphorhodamine B (SRB) method is a cytotoxicity assay based on the measurement of cellular protein content. Following the experimental protocol described above, the growth medium was removed from 96-well plates and cell monolayers were fixed with $50 \%$ (vol/vol) trichloroacetic acid for $1 \mathrm{~h}$ at $4{ }^{\circ} \mathrm{C}$, subsequently washed (five times) in cold water and desiccated. Then, cell staining was performed using $0.4 \% \mathrm{SRB}$ in $1 \%$ acetic acid ( $\mathrm{POCH}$, Poland) for $30 \mathrm{~min}$ at room temperature. After the incubation, the dye was removed by washing repeatedly (four times) with $1 \%$ (vol/vol) acetic acid. Plates were desiccated and the protein-bound dye was dissolved in $10 \mathrm{mM}$ Tris base
(Sigma-Aldrich, Poland) (pH 10.5) solution for absorbance determination at $490 \mathrm{~nm}$ using a microplate reader (GloMax Discovery, Promega). The results were expressed as the percentage of cell viability relative to the untreated control cells $(1 g)$.

\section{MTT assay}

A standard MTT [3-(4,5-dimethylthiazol-2-yl)-2,5diphenyltetrazolium bromide] assay (MTT, Sigma-Aldrich) was performed to analyse the mitochondrial function. After the appropriate time of incubation, growth medium was removed from 96-well plates and the cells were incubated for $2 \mathrm{~h}$ at $37^{\circ} \mathrm{C}$ in $100 \mu \mathrm{L} /$ well MTT solution $(0.5 \mathrm{mg} / \mathrm{ml}$ of PBS buffer); then $100 \mu \mathrm{L}$ of the acidified isopropanol $(0.04 \mathrm{M}$ $\mathrm{HCl}$ in absolute isopropanol) was added to each well to dissolve the formazan crystals. The absorbance was measured at $560 \mathrm{~nm}$ using a microplate reader (GloMax Discovery, Promega). The results were expressed as the percentage of cells mitochondrial activity relative to untreated control cells $(1 \mathrm{~g})$.

\section{Cell Death Assays}

24 or $72 \mathrm{~h}$ after clinorotation, the culture medium was collected, the cells were washed with PBS buffer and detached from the surface using a trypsin-EDTA solution. The collected growth medium and cell suspension were centrifuged $(6720 \times g)$ for $10 \mathrm{~min}$ at $4{ }^{\circ} \mathrm{C}$. Half of the cells were stained with Annexin V-APC Apoptosis Kit with PI (BioLegend, cat. no. 640932) and analysed with CUBE6 flow cytometer (Sysmex) in order to indicate the percentage of early and late apoptotic and necrotic cells. The remaining cells were used for the neutral comet assay method described by Collins (Collins 2002) to detect DNA damages in SKOV-3 cells associated with the exposure to $s \mu m$. The cells at the concentration of $1 \times 10^{5} / \mathrm{ml}$ in PBS were mixed with low temperature melting agarose (Sigma-Aldrich) at ratio 1:10 $(\mathrm{v} / \mathrm{v})$ and spread on a slide $\left(1 \times 10^{2}\right.$ cells $\left./ \mathrm{cm}^{2}\right)$. Slides were submerged in precooled lytic solution $(2.5 \mathrm{M} \mathrm{NaCl}, 100 \mathrm{mM}$ EDTA, pH 10, $10 \mathrm{mM}$ Tris base and $1 \%$ Triton X-100) at $4{ }^{\circ} \mathrm{C}$ for $60 \mathrm{~min}$. After lysis and rinsing, slides were equilibrated in TBE solution ( $40 \mathrm{mM}$ Tris/boric acid, $2 \mathrm{mM}$ EDTA, pH 8,3), electrophoresed at 1,2 V/cm for $15 \mathrm{~min}$; then silver staining was performed (Nadin et al. 2001). For scoring the comet patterns, 200-300 nuclei from each slide were assessed.

\section{Cell Cycle Assay}

24 or $72 \mathrm{~h}$ after clinorotation, the cells were detached from 6 -well plates and the collected growth media and cell suspensions were centrifuged $(6720 \times g)$ for $10 \mathrm{~min}$ at $4{ }^{\circ} \mathrm{C}$. 
Then, the cells were fixed in cold ethanol $(70 \%)$ at $4{ }^{\circ} \mathrm{C}$ for $24 \mathrm{~h}$. Subsequently, the cells were washed with PBS, centrifuged $\left(6720 \times g\right.$ for $10 \mathrm{~min}$ at $\left.4{ }^{\circ} \mathrm{C}\right)$ and incubated with RNAse solution $(100 \mu \mathrm{g} / \mathrm{ml}$ in PBS buffer; A\&A Biotechnology, cat. no. 1006-10) at room temperature for $30 \mathrm{~min}$. After that, propidium iodide (PI; Sigma Aldrich, cat. no. 81845) was added to obtain the final concentration $50 \mu \mathrm{g} / \mathrm{ml}$ and the cells were stained in the dark for $30 \mathrm{~min}$. The percentage of G0/G1, S and G2 cells was assessed by CUBE6 flow cytometer (Sysmex, Poland).

\section{Clonogenic assay}

Clonogenic assay is a technique enabling to assess the cell survival and proliferation following the exposure to the simulated microgravity. After clinorotation, the cells were plated in appropriate dilutions $\left(15 \mathrm{cells} / \mathrm{cm}^{2}\right)$ on 6-well-plates. Multi-well-plates were placed in an incubator and left there for 7 days until large colonies $(>1 \mathrm{~mm})$ were formed (50 cells or more). After incubation, the growth medium was removed and the cells were washed with PBS. Fixation and staining of clones was performed with a mixture of $0.5 \%$ crystal violet (Sigma-Aldrich, USA) in 4\% paraformaldehyde for $10 \mathrm{~min}$. Then, the plates were rinsed with water and left to dry at room temperature. Counting of clones was performed the following day using OpenCFU software.

\section{Migration Assay}

Cell migration was performed in Boyden chambers (ThinCert ${ }^{\mathrm{TM}}$ Cell Culture Inserts) produced by Greiner Bio-One. After clinorotation, the cells were suspended in serum-free DMEM and then $1 \times 10^{3}$ cells/well were seeded onto inserts $(8 \mu \mathrm{m}$ pore size $)$ in 24 -well plates. Fetal bovine serum (10\%) in DMEM was used as a chemoattractant for the cells cultivated on the bottom layer. After 24 or $74 \mathrm{~h}$, fixation and staining of cells was done with a mixture of $0.5 \%$ crystal violet in $4 \%$ paraformaldehyde for $10 \mathrm{~min}$. Subsequently, the inserts were rinsed with PBS and the cells from the upper part of the membrane were removed using a cotton scraper, and the inserts - left to dry at room temperature. Cells that had invaded the lower surface of the filters were counted using inverted light microscopy at a magnification of 400 . The migration index was calculated in comparison to $1 \mathrm{~g}$, untreated cells, performed by counting cells from app. 10 different fields of view.

\section{Confocal Microscopy}

Confocal laser scanning microscopy (CLMS) was used for the visualization of cell morphology. After the experiment, the cells were washed 3 times with PBS and fixed using 4\% paraformaldehyde (PFA, Sigma-Aldrich) for $10 \mathrm{~min}$. Then, the cells were submerged in staining solution HCS CellMask $^{\mathrm{TM}}$ Green Stain (Molecular Probes, Cat. no. H32714, Ex./Em. 493/516 nm) and incubated for $15 \mathrm{~min}$ at room temperature. HCS CellMask ${ }^{\mathrm{TM}}$ Stains label the entire cell (cytoplasm and nucleus) for a more thorough description of the cell's anatomy and provide an accurate backdrop against which the features of interest can be evaluated. Next, the staining solution was removed, and the dishes were rinsed with PBS three times. After washing out with PBS, the nuclear DNA was stained with DAPI (4,6-diamidino2-phenylindole; $0.2 \mu \mathrm{g} / \mathrm{ml}$, Ex./Em. 358/461 nm). In the end, the cells were mounted in fluorescence mounting medium (DAKO). For F-actin visualization, the dishes were blocked with $1 \%$ BSA for $1 \mathrm{~h}$. Next, they were washed 3 times with $1 \%$ Triton X-100 and, then incubated with Alexa Fluor ${ }^{\mathrm{TM}}$ 546 Phalloidin (1:100 in PBS; cat. no. A22283) at $4{ }^{\circ} \mathrm{C}$ for $24 \mathrm{~h}$. Next, the coverslips were rinsed with PBS three times, stained with and mounted in fluorescence mounting medium. For imaging, the Olympus FluoView FV1000 confocal laser scanning microscope (Olympus) was used. The images were recorded by employing a Plan-Apochromat $60 \times$ oil-immersion objective.

\section{Statistics}

Statistical significance was determined by two-way ANOVA with Tukey post-hoc test within groups following a normal distribution. Samples were analysed in at least four replications in three independent experiments. Differences between the treated samples and the control cells with $\mathrm{p}$ values $\leq 0.05$ were assumed to be statistically significant. The results were analysed with the Microsoft Office Excel 2017 and GraphPad Prism 7.0 software.

\section{Results}

Following clinorotation, we observed a decrease of SKOV-3 cells viability exposed to simulated microgravity (Fig. 1A). The presence of cisplatin caused a slight decrease in the SKOV-3 cell viability in comparison to $1 g$ static cells, especially $72 \mathrm{~h}$ after the rotation (79.64\%).

The mitochondrial activity of cancer cells incubated without cisplatin remained unchanged $(\sim 100 \%)$ for $1 \mathrm{~g}$ and $\mathrm{s} \mu \mathrm{m}$ groups in 24 and $72 \mathrm{~h}$. However, the mitochondrial functioning was considerably affected when the clinorotated cells were cultured with cisplatin (Fig. 1B, 85\% in $72 \mathrm{~h}$ ).

According to our research, the exposure to the simulated microgravity slightly increased cell death of SKOV-3 cells, even in the presence of cisplatin (Fig. 2). The dominant process was necrosis, whereas the percentages of apoptotic cells were less than $2 \%$ in all samples, which remains in accordance with both flow cytometry and comet assay. For cells 
Fig. 1 The viability $\mathbf{A}$ and mitochondrial activity $\mathbf{B}$ of SKOV-3 cells 24 and $72 \mathrm{~h}$ after clinorotation with or without cisplatin at the concentration of $25 \mu \mathrm{M}$. *statistically significant differences in comparison to $1 \mathrm{~g}$, not clinorotated cells $(p \leq 0.05)$
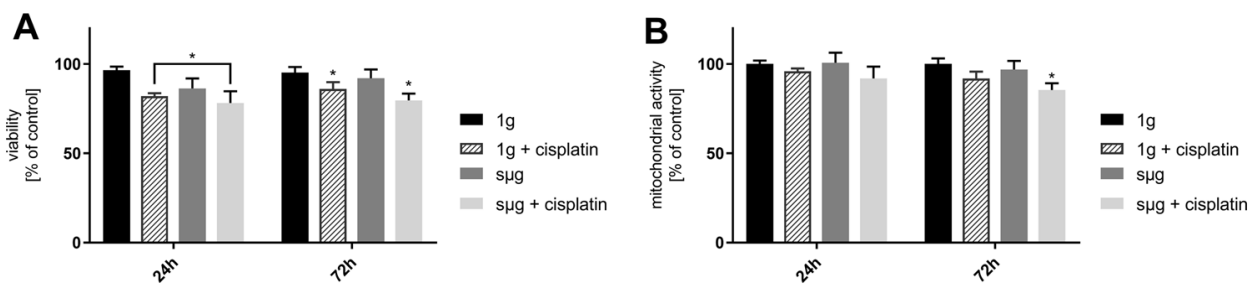

subjected to $s \mu g$ and pre-treated with cDDP, the percentage of necrotic cells was $13.42 \%$ in the case of flow cytometry analysis and $15 \%$ for the comet assay. Interesting alterations were shown within the comet evaluation - we observed an increase in the number of intermediately damaged nuclei in $s \mu g$ groups, especially for cisplatin pre-cultured cells.

The evaluation of the cell cycle of SKOV-3 cells treated with cisplatin and subjected to simulated microgravity

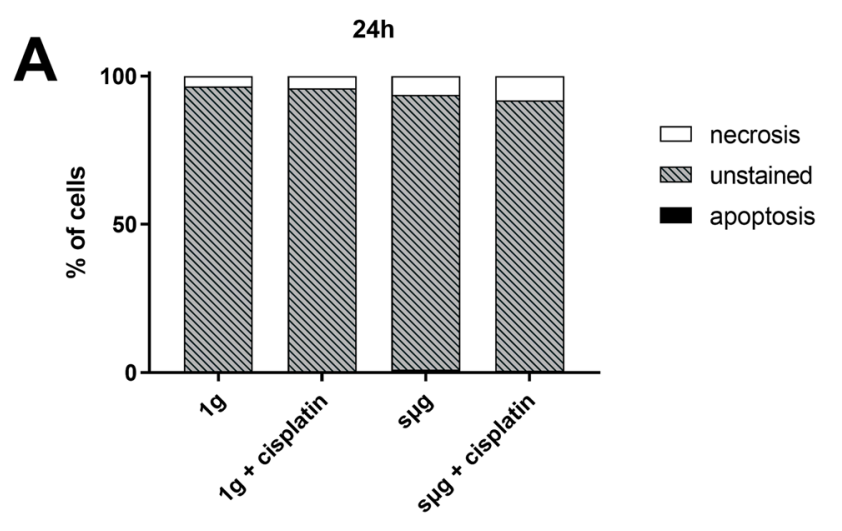

19

C

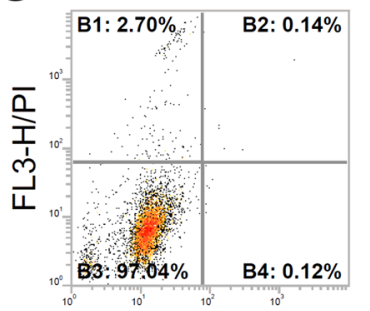

FL1-H/Annexin V

D

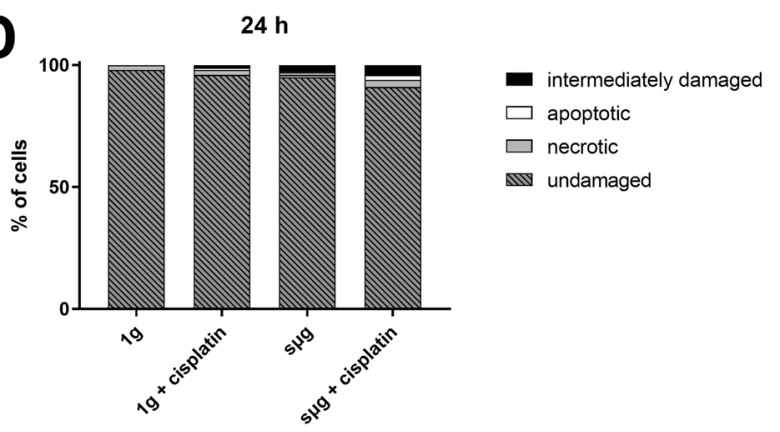

Fig. 2 Cell death evaluation of SKOV-3 cells 24 and $72 \mathrm{~h}$ after the exposure to simulated microgravity. The percentage ratio of undamaged, necrotic and apoptotic cells 24 or $72 \mathrm{~h}$ after clinorotation with or without cisplatin at the concentration $25 \mu \mathrm{M}$ analysed with flow

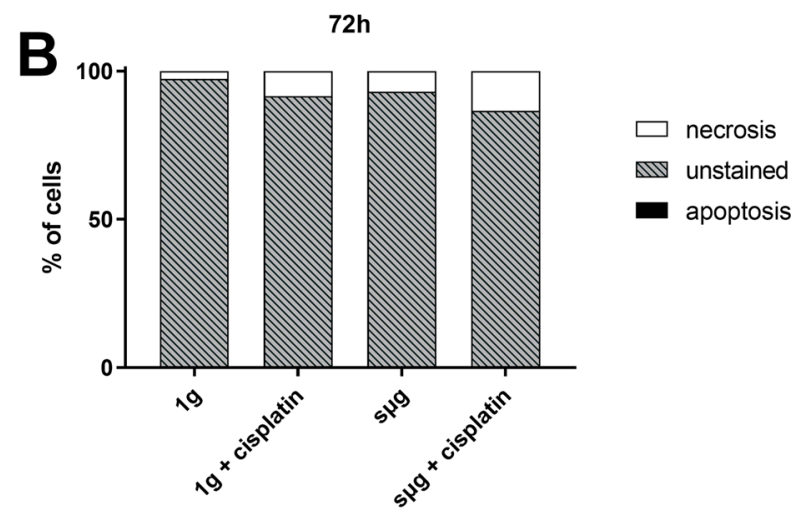

sug

sug + cisplatin

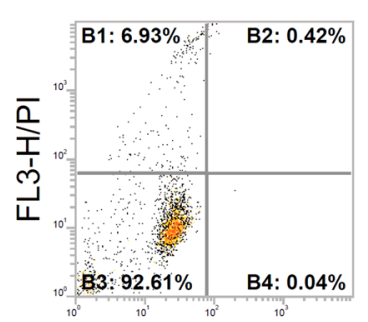

FL1-H/Annexin V

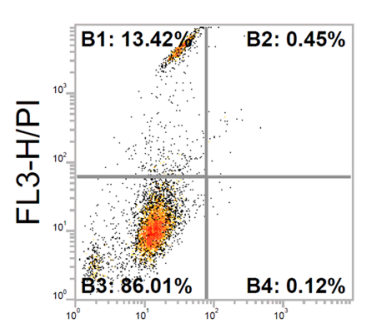

FL1-H/Annexin V

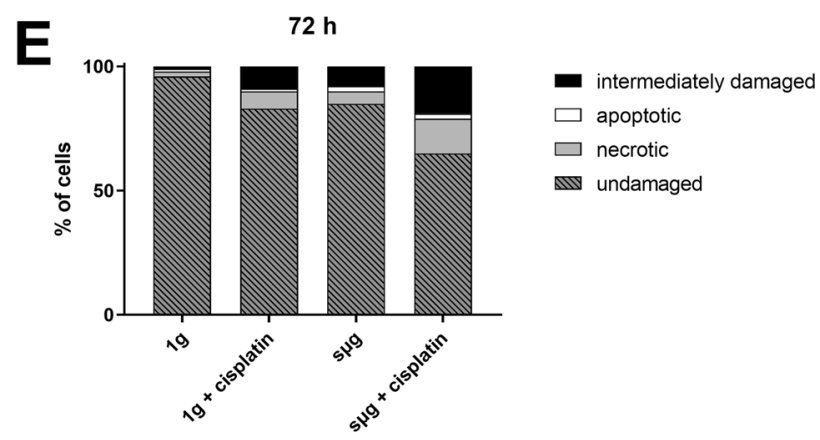

cytometry (A, B) and the representative dot blots of SKOV-3 cells $72 \mathrm{~h}$ after the 3D clinorotation C; gate B1 necrotic, gate B2 late apoptotic, gate B3 undamaged, gate B4 early apoptotic cells. Comparative analyses were performed with comet assay $(\mathbf{D}, \mathbf{E})$ 
(Fig. 3) showed a significant alteration in percentage ratios of cells in G1/G0, S and $\mathrm{G} 2$ phases. $24 \mathrm{~h}$ after clinorotation we observed a decrease in the percentage ratio of cells in the $\mathrm{S}$ phase, especially when the cells were cultured with cDDP during the rotation. Simultaneously, our studies revealed an increased ratio of cells in G1/G0 and G2 phases. We noticed that syg exposure induced similar G0/G1 cell cycle arrest as observed for $1 \mathrm{~g}$ cells cultured with cDDP $(81.14 \%$ vs $82.14 \%$ ). Additionally, the highest ratio of cells in the G1/ G0 phase was measured among the groups subjected to $s \mu g$ and pre-treated with cDDP $(87.28 \%)$.

The clonogenic assay confirmed the detrimental impact of simulated microgravity and cisplatin administration, which decreased the cell proliferation (Fig. 4). Differences in the number of colonies between the $1 \mathrm{~g}$ and $s \mu \mathrm{m}$ cells indicate the cytotoxic properties of clinorotation. Furthermore, this assay revealed that the proliferation of SKOV-3 cells incubated with cisplatin was almost the same as in the cells subjected to simulated gravity without incubation with cDDP (68.63\% vs $71.82 \%)$. We observed smaller and less abundant colonies in $s \mu g$ groups cells, especially among the cells pre-treated with cisplatin $(41.36 \%)$. In comparison to the viability, cell death, and cell cycle assays, the clonogenic assay revealed the strongest alterations in cell functioning of SKOV-3 cells cultured with cDDP and exposed to $s \mu m$.

Except for the abovementioned phenomena, cell migration was also suppressed when the cells had been previously subjected to simulated microgravity (Fig. 5). We observed significant alterations already $24 \mathrm{~h}$ after the clinorotation. The strongest changes in migration index (MI) were observed $72 \mathrm{~h}$ after the exposure to clinorotation and cDDP (MI 31.25\%). For s $\mu m$ cells we observed a strong decrease of MI after $72 \mathrm{~h}$ in comparison to the cells cultured for $24 \mathrm{~h}(81.40 \%$ vs $53.13 \%)$, whereas for $s \mu m$ cells and those exposed to cDDP, no such occurrence was noted.

Fluorescence staining revealed serious differences in the cell morphology after the exposure to simulated microgravity for $2 \mathrm{~h}$ (Fig. 6). After clinorotation, the cells were shrunken and round shaped. We observed the altered cell shape, presence of membrane blebbing and lamellipodia, lack of filopodia, the presence of stress fibers and the accumulation of cytoskeletal fibres at the peripheral area of the cell. Cytoskeleton staining (Fig. 7) revealed characteristic reorganization of F-actin fibers when the cells were exposed to $s \mu m$. The fibers were disrupted and accumulated in peripheral parts of cells. Moreover, the nuclei were slightly enlarged.

\section{$24 \mathrm{~h}$}
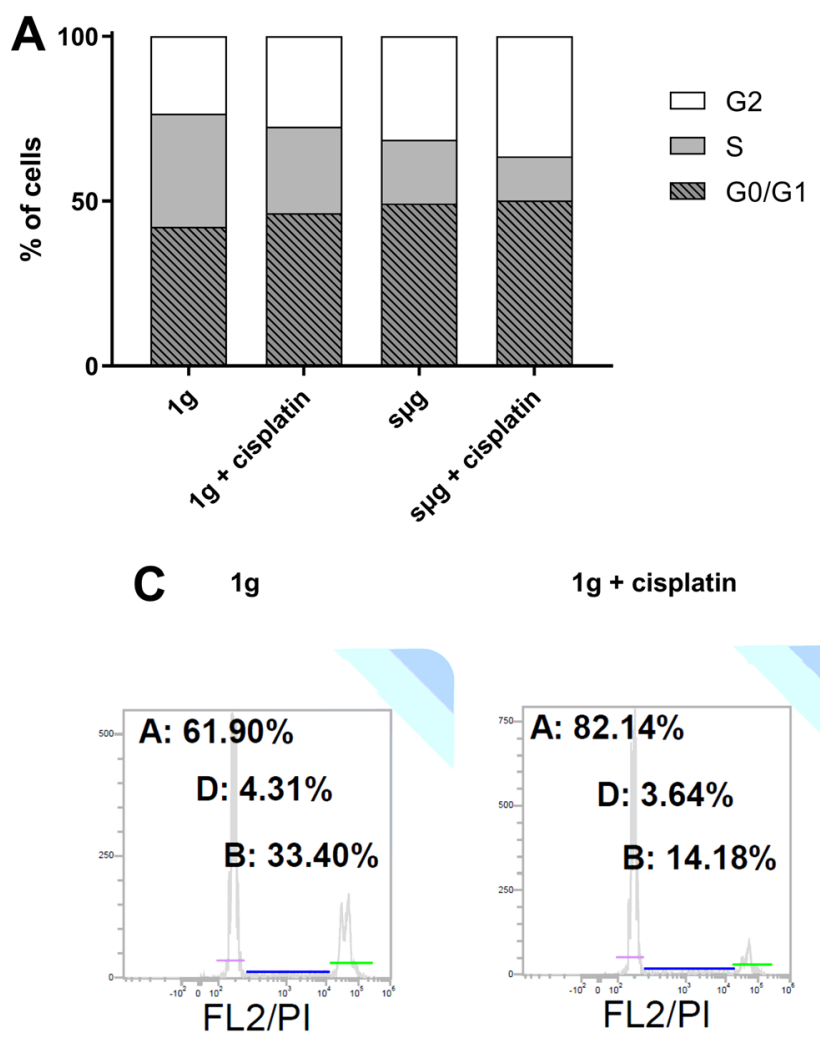

$\mathrm{FL} 2 / \mathrm{PI}$
Fig. 3 Cell cycle analysis of SKOV-3 cells 24 and $72 \mathrm{~h}$ after the exposure to simulated microgravity. The percentage ratio of G0/G1, $\mathrm{S}$ and $\mathrm{G} 2$ cells 24 or $72 \mathrm{~h}$ after clinorotation with or without cisplatin
$72 \mathrm{~h}$
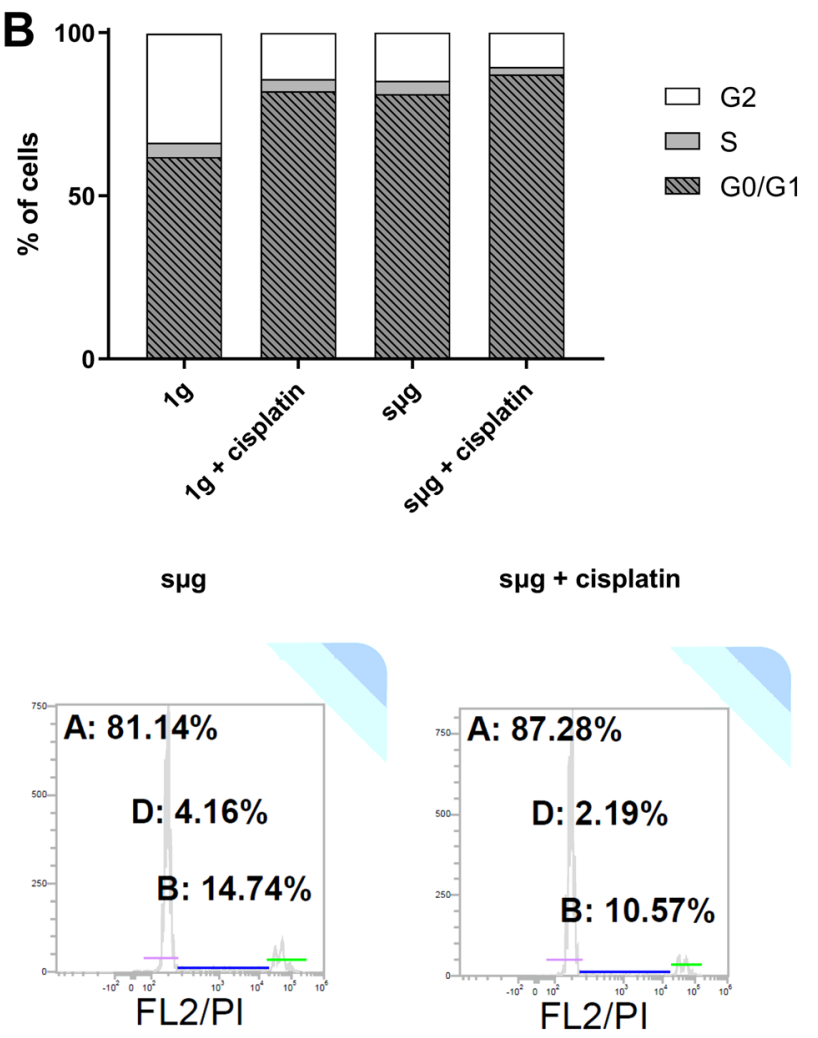

at the concentration $25 \mu \mathrm{M}$ analysed with flow cytometry (A, B) and the representative histograms of SKOV-3 cells $72 \mathrm{~h}$ after the rotation on 3D-C C; gate A - G0/G1 phase, gate D - S phase, gate B - G2 phase 
A

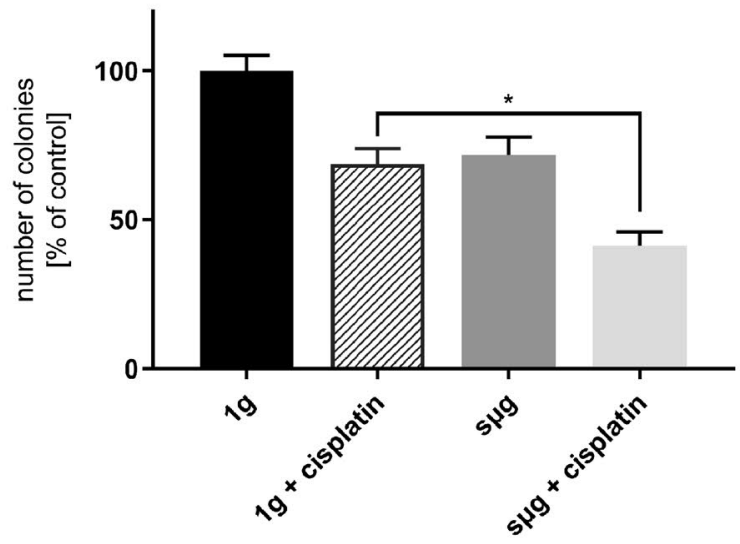

B

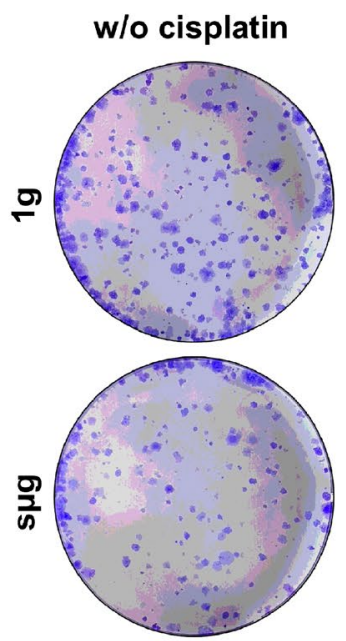

with cisplatin

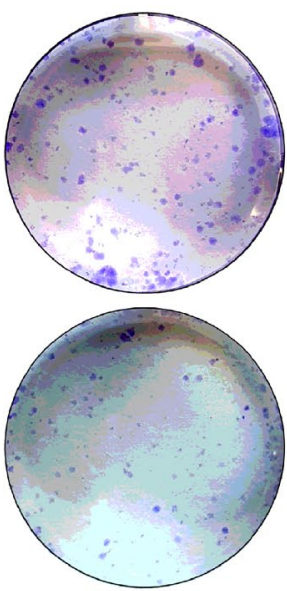

Fig. 4 Number of colonies (\% of control cells) after the exposure to simulated microgravity with or without cisplatin at the concentration $25 \mu \mathrm{M} \mathrm{A}$ and 7-day incubation of SKOV-3 cells $(* \mathrm{p} \leq 0.05$; data are

\section{Discussion}

In this study, we investigated the combined effects of shortterm $s \mu g$ and cisplatin treatment on a multidrug-resistant model of human ovarian cancer in vitro. Our experiments provide considerable insight into the modulation of multidrug resistance phenomena triggered by $s \mu g$. The results are consistent with previous reports of Piepmeier et al. (1997), which proved that prolonged microgravity for $72 \mathrm{~h}$ had affected the doxorubicin influx and enhanced drug efficiency in HL-60 cells, demonstrating the correlation between cytoskeletal changes and drug administration in cancer cells. Other authors that used SGC-7901 cancer cell model also demonstrated the significant changes in cellular morphology and biological characteristics during clinostat-simulated weightlessness within $72 \mathrm{~h}$ (Zhu et al. 2014). presented as the mean amount of counted colonies); the representative pictures of colonies $\mathbf{B}$

It was revealed that even relatively short exposure of $2 \mathrm{~h}$ to simulated microgravity applied in our study was sufficient to observe characteristic morphological effects, already well-described in the literature: the altered, rounded shape of the cells, peripheral cytoskeleton accumulation or membrane blebbing (Rudimov and Buravkova 2016). Interestingly, it was also noted that cancer cells were able to form complex 3D spheroid structures in real and simulated microgravity (Chen et al. 2019; Grimm et al. 2020; Kopp et al. 2018). According to the previous studies, the underlying cause of the observed changes should be the disruption of the cytoskeleton, which might not only influence the MDR phenomenon but also affect the migration index of the cells. Remarkably, there is still a considerable ambiguity on the issue of cancer cells' motility after the exposure to the $s \mu g$. Even though our results
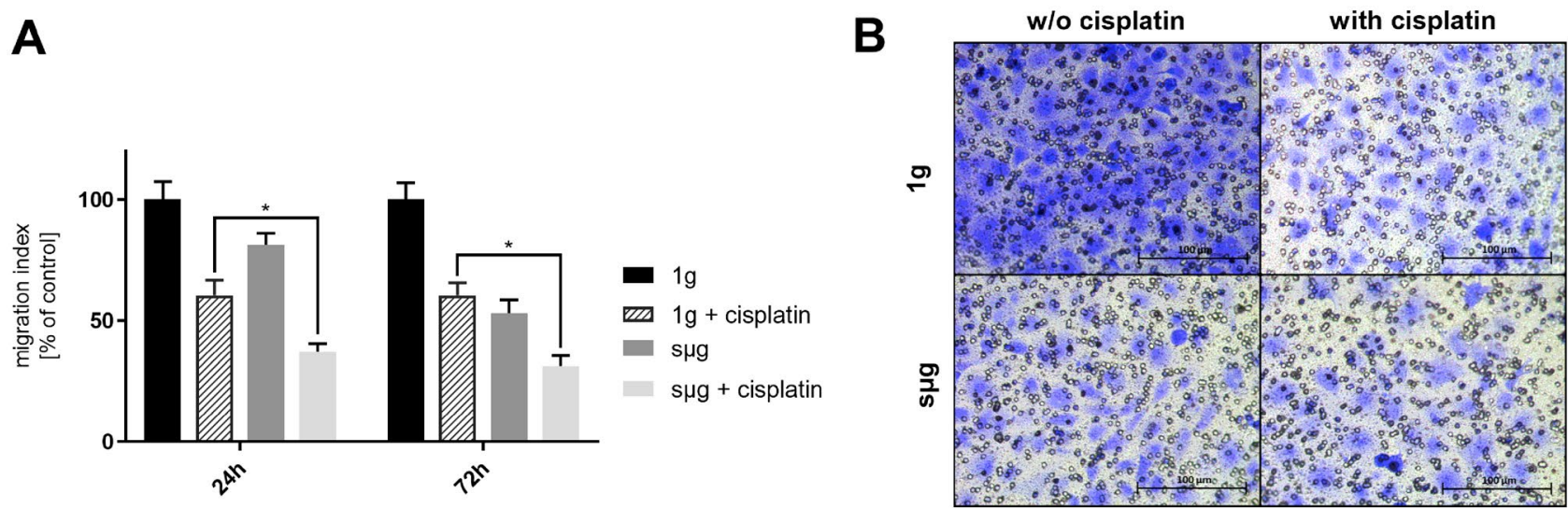

Fig. 5 Migration index (\% of control) of SKOV-3 cells after the exposure to simulated microgravity with or without cisplatin at the concentration $25 \mu \mathrm{M}$ A and 24 or $72 \mathrm{~h}$ of incubation. The representative pictures of the stained membranes B; scale bars: $100 \mu \mathrm{m}$ 


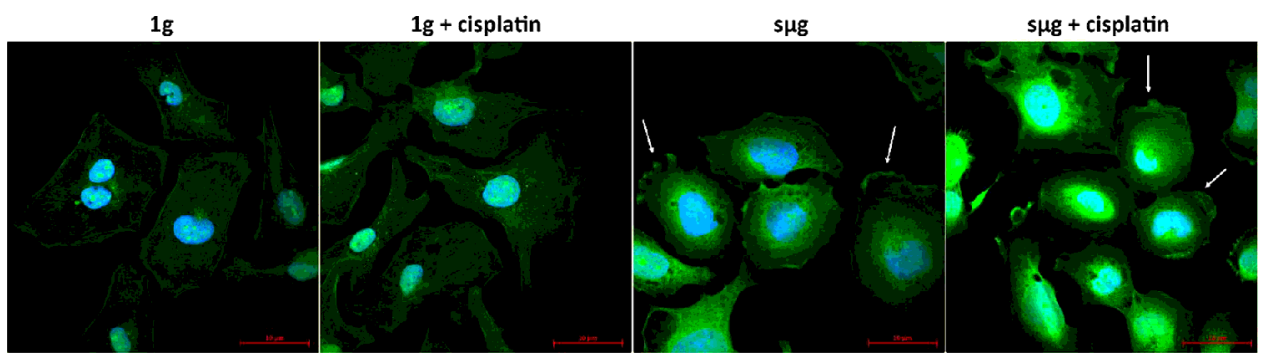

Fig. 6 The representative photographs of the morphology of SKOV-3 cells exposed to $2 \mathrm{~h}$ to simulated microgravity with or without cisplatin at the concentration $25 \mu \mathrm{M}$, fixed immediately after clinorotation and stained with HCS CellMask ${ }^{\mathrm{TM}}$ Green Stain (cell membrane and cytoplasm) and DAPI (nuclei); scale bars: $10 \mu \mathrm{m}$

cells. It is interesting to note that differences may emerge from the unique behavior of each cell line exposed to $s \mu g$, while such research on ovarian cancer cells has never been performed. Our experiments revealed that treatment with cisplatin decreases the migration index of ovarian cancer significant decrease in metastatic potential of malignant

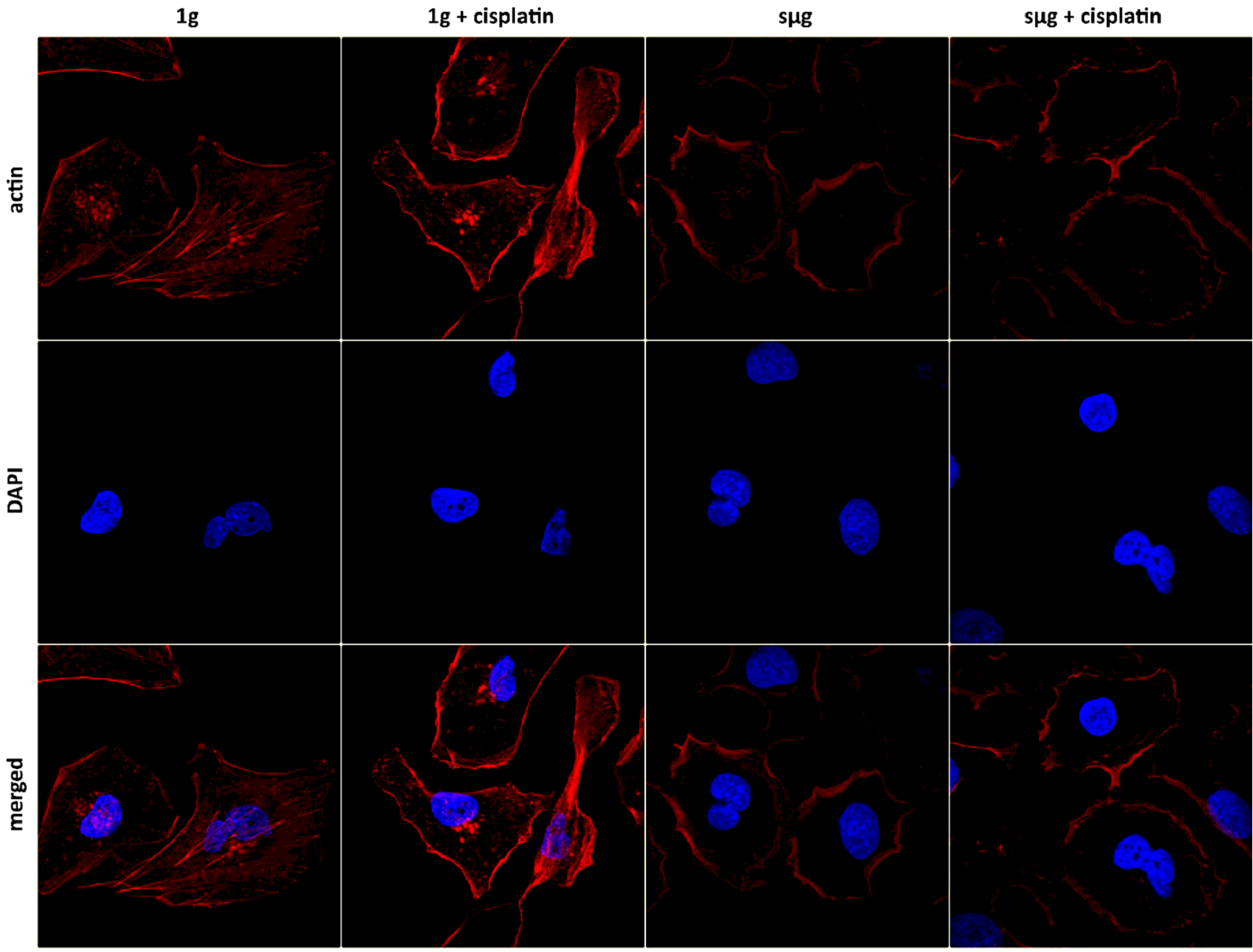

Fig. 7 The representative photographs of the F-actin cytoskeleton and DAPI (nuclei) of SKOV-3 cells exposed for $2 \mathrm{~h}$ to simulated microgravity with or without cisplatin at the concentration $25 \mu \mathrm{M}$, fixed immediately after clinorotation; scale bars: $10 \mu \mathrm{m}$ 
cells by itself, but in combination with $s \mu g$ the effect is severely enhanced, regardless of the duration of subsequent culturing after the stimuli. On the other hand, the observed alterations might also occur from the different simulation approaches and different operational modes of clinostat types. Krause et al. (2018) reported that adding a second rotation axis in case of 3D clinorotation did not increase the quality of microgravity simulation, but provide disturbances such as the increased level of vibrations (Krause et al. 2018). Brungs et al. (2019) also observed various cellular responses using different types of simulated microgravity facilities and rotation protocols (Brungs et al. 2019). Thus, further research may include a comparative analysis of SKOV-3 cells response to simulated gravity using 2D- and 3D-clinostats at the rotation speed between 5-60 rpm.

Not much is known about the proliferation rates after the short-term exposure to $\mu g$; yet the decreased values of the colony formation observed in our experiment remain in accordance with some studies concerning prolonged (from $12 \mathrm{~h}$ to 3 days) cultivation of cancer cells in such conditions, displaying weaker proliferation (Chang et al. 2013; Chung et al. 2017; Vidyasekar et al. 2015) or even growth inhibition (Xu et al. 2018). Curiously, a few other studies addressing this issue reported contradictory effects between different cell lines; some of them proliferated normally when they were subjected to simulated and real $\mu \mathrm{g}$ conditions (Chung et al. 2017; Kim et al. 2017).

No substantial differences were found between control and experimental groups in viability assays. Moreover, we have noted perfect agreement between comet assay and propidium iodide/annexin $\mathrm{V}$ staining indicating the lack of apoptosis after the $2 \mathrm{~h}$ of $s \mu g$. That phenomenon has been reported previously for short-term exposure to real $\mu g$ during the parabolic flights, showing well-maintained cells' viability (Wehland et al. 2015), and no significant signs of apoptosis (Nassef et al. 2019), confirmed by a detectable rise in antiapoptotic genes expression after the $31^{\text {st }}$ parabola (Wehland et al. 2015). However, we observed the cumulative cytotoxic effect of cisplatin and $s \mu g$ exhibited through the considerable rise in the percentage of necrotic cells and elevated levels of intermediate DNA damages. On the other hand, some studies reported morphological and biochemical signs of apoptosis in endothelial cells within $4 \mathrm{~h}$ of exposure of simulated microgravity (Infanger et al. 2006a), which were further increased after $72 \mathrm{~h}$ (Infanger et al. 2006a; Kang et al. 2011a).

The single most conspicuous observation to emerge from the data is the significant dysregulation of the cell cycle of cells subjected to $s \mu g$. Not only did $s \mu g$ cause strikingly similar cell cycle arrest in G1/G0 phased as observed for cells in $1 \mathrm{~g}$ treated with cDDP, but also was the synergistic effect of both clearly visible. This concurs with the clonogenic assay, explaining the decreased proliferation despite lack of apoptotic events. Crucially, those early-observed changes are in good agreement with much longer experiments (2496 h) reporting subG0 (Arun et al. 2017; Vidyasekar et al. 2015) or G1 cell cycle arrest (Sokolovskaya et al. 2014) after the exposure to $s \mu g$. Subsequent cultivation under the $s \mu g$ $(120 \mathrm{~h})$ has been reported to mitigate this effect, suggesting the progressive adaptation of the cells (Sokolovskaya et al. 2014). However, it is worth mentioning that those effects were accompanied not only by deregulated proliferation, but also decreased in viability due to prolonged exposure to $s \mu \mathrm{g}$ (Arun et al. 2017; Vidyasekar et al. 2015).

Disturbance of $\alpha$ and $\beta$ tubulin, commonly observed after the exposure to $s \mu g$ or $\mu g$, has been proven to provide the increased susceptibility to cisplatin, leading to the increased apoptosis induction caused by cytostatic drug (Kyu-Ho Han et al. 2000; Pei et al. 2007). Additionally, the cytoskeleton interacts with MDR proteins located in lipid rafts of cell membrane and affects their activity without altering the gene expressions (Bacso et al. 2004), whereas gravity variations are suspected of remodeling the cell membrane structure by altering lipid rafts (Albi et al. 2014) and thus, affecting drug sensitivity. Based on our findings, revealing the altered cell morphology and increased anticancer effect of cDDP of SKOV-3 cells subjected to $s \mu g$ and the abovementioned studies, we claim that the forthcoming research should focus on the association between cytoskeleton, cell membrane as well as MDR-related proteins and the molecular pathways responsible for their regulation and interactions.

As discussed above, the response to an altered gravity significantly varies among different models and durations of the experiments. Therefore, it should be emphasized that the effects described in this study originate from only a short-term $s \mu g$ treatment and that longer exposure times shall be investigated to evaluate the spectrum of physiological responses of ovarian cancer cells and to confirm their significance.

\section{Conclusions}

In summary, this is the first in vitro study revealing the relationship between simulated microgravity and multidrug resistance in human ovarian cancer cells. Gravity alterations seems to be a significant factor that strongly affects the functioning of human ovarian cancer cells (SKOV-3) in the presence of the cytostatic drug. Our studies have revealed intriguing alterations in the cell cycle, namely G1/G0 cell cycle arrest induced by the short-time exposure to simulated microgravity and simultaneous administration of cisplatin without a strong effect in cell viability. The observed phenomena were accompanied by changes in cell membrane morphology (rounded shape, presence of membrane blebbing and lamellipodia and lack of filopodia), decreased 
migration and proliferation index of SKOV-3 cells indicating an occurrence of the synergic effect of cisplatin and $s \mu g$. Based on these findings, we believe that $s \mu \mathrm{g}$ may affect cell pathways involved in multidrug resistance, especially those associated with cell membrane and cytoskeleton, resulting in higher sensitivity of cancer cells to chemotherapeutics. The investigation and clarification of these phenomena may constitute the initial step toward enhancing our understanding of the relationship between the cellular resistance to chemotherapy and the response to various gravitational and biophysical stimuli.

Acknowledgments We are particularly grateful to Ms Anna Korneluk and $\mathrm{Mr}$ Adrian Michoński for the project and construction of 3D-C employed in this research. The authors would like to thank Ms. E. Przydatek for the correction of the English language in the manuscript.

Authors' contributions DP was responsible for project administration. DP and AG wrote the original draft and performed most of the experimentation. AS was responsible for CLSM. MD-Z helped with comet assay. JK was the supervisor of the experiment and the main reviewer. All authors reviewed the manuscript.

Funding The research was supported partially by the Statutory Funds of Wroclaw Medical University (Department of Molecular and Cellular Biology) no. SUB.D260.20.009 and the project was financed with the funds granted by the National Centre for Research and Development, project number POIR.04.01.01-00-0010/19-00.

Availability of data and material Data available on request from the authors.

\section{Declarations}

Conflict of Interest The authors declare that they have no conflict of interest.

Open Access This article is licensed under a Creative Commons Attribution 4.0 International License, which permits use, sharing, adaptation, distribution and reproduction in any medium or format, as long as you give appropriate credit to the original author(s) and the source, provide a link to the Creative Commons licence, and indicate if changes were made. The images or other third party material in this article are included in the article's Creative Commons licence, unless indicated otherwise in a credit line to the material. If material is not included in the article's Creative Commons licence and your intended use is not permitted by statutory regulation or exceeds the permitted use, you will need to obtain permission directly from the copyright holder. To view a copy of this licence, visit http://creativecommons.org/licenses/by/4.0/.

\section{References}

Ahn, C.B., Lee, J.H., Han, D.G., Kang, H.W., Lee, S.H., Lee, J.I., Son, K.H., Lee, J.W.: Simulated microgravity with floating environment promotes migration of non-small cell lung cancers. Sci. Rep. 9, 1-10 (2019). https://doi.org/10.1038/s41598-019-50736-6

Albi, E., Curcio, F., Lazzarini, A., Floridi, A., Cataldi, S., Lazzarini, R., Loreti, E., Ferri, I., Ambesi-Impiombato, F.S.: A Firmer Understanding of the Effect of Hypergravity on Thyroid Tissue:
Cholesterol and Thyrotropin Receptor. PLoS ONE 9, e98250 (2014). https://doi.org/10.1371/journal.pone.0098250

Arun, R.P., Sivanesan, Di., Vidyasekar, P., Verma, R.S.: PTEN/ FOXO3/AKT pathway regulates cell death and mediates morphogenetic differentiation of Colorectal Cancer Cells under Simulated Microgravity. Sci. Rep. 7, 1-15 (2017). https://doi. org/10.1038/s41598-017-06416-4

Bacso, Z., Nagy, H., Goda, K., Bene, L., Fenyvesi, F., Matkó, J., Szabó, G.: Raft and cytoskeleton associations of an ABC transporter: P-glycoprotein. Cytom. Part A 61, 105-116 (2004). https://doi.org/10.1002/cyto.a.20081

Basu, A., Krishnamurthy, S.: Cellular responses to cisplatin-induced DNA damage. J. Nucleic Acids. 2010, (2010). https://doi.org/ $10.4061 / 2010 / 201367$

Borst, A.G., Van Loon, J.J.W.A.: Technology and developments for the random positioning machine. RPM. Microgravity Sci. Technol. 21, 287-292 (2009). https://doi.org/10.1007/ s12217-008-9043-2

Brungs, S., Hauslage, J., Hemmersbach, R.: Validation of Random Positioning Versus Clinorotation Using a Macrophage Model System. Microgravity Sci. Technol. 31, 223-230 (2019). https://doi. org/10.1007/s12217-019-9687-0

Chang, D., Xu, H., Guo, Y., Jiang, X., Liu, Y., Li, K., Pan, C., Yuan, M., Wang, J., Li, T., Liu, C.: Simulated microgravity alters the metastatic potential of a human lung adenocarcinoma cell line. Vitr. Cell. Dev. Biol. - Anim. 49, 170-177 (2013). https://doi.org/ 10.1007/s11626-013-9581-9

Chen, J.: Tumor Cells in Microgravity. In: Into Space - A Journey of How Humans Adapt and Live in Microgravity. p. 64. InTech (2018)

Chen, Z.Y., Guo, S., Li, B.B., Jiang, N., Li, A., Yan, H.F., Yang, H.M., Zhou, J.L., Li, C.L., Cui, Y.: Effect of Weightlessness on the 3D Structure Formation and Physiologic Function of Human Cancer Cells. (2019). https://doi.org/10.1155/2019/4894083

Chung, J.H., Ahn, C.B., Son, K.H., Yi, E., Son, H.S., Kim, H.S., Lee, S.H.: Simulated Microgravity Effects on Nonsmall Cell Lung Cancer Cell Proliferation and Migration. Aerosp. Med. Hum. Perform. 88, 82-89 (2017). https://doi.org/10.3357/AMHP.4647.2017

Collins, A.R.: The Comet Assay: Principles, Applications, and Limitations. In: In Situ Detection of DNA Damage. pp. 163-177. Humana Press, New Jersey (2002)

Corydon, T.J., Kopp, S., Wehland, M., Braun, M., Schütte, A., Mayer, T., Hülsing, T., Oltmann, H., Schmitz, B., Hemmersbach, R., Grimm, D.: Alterations of the cytoskeleton in human cells in space proved by life-cell imaging. Sci. Rep. 6, 1-14 (2016). https://doi.org/10.1038/srep20043

Crawford-Young, S.J.: Effects of microgravity on cell cytoskeleton and embryogenesis. Int. J. Dev. Biol. 50, 183-191 (2006). https://doi. org/10.1387/ijdb.052077sc

Gonzalez-Martin, A., Raja, F.A., Colombo, N., Sessa, C., Fotopoulou, C., Ledermann, J.A.: Newly diagnosed and relapsed epithelial ovarian carcinoma: ESMO Clinical Practice Guidelines for diagnosis, treatment and follow-up. Ann. Oncol. 24, vi24-vi32 (2013). https://doi.org/10.1093/annonc/mdt333

Grimm, D., Wehland, M., Corydon, T.J., Richter, P., Prasad, B., Bauer, J., Egli, M., Kopp, S., Lebert, M., Krüger, M.: The effects of microgravity on differentiation and cell growth in stem cells and cancer stem cells. Stem Cells Transl. Med. 9, 882-894 (2020). https://doi.org/10.1002/sctm.20-0084

Herranz, R., Anken, R., Boonstra, J., Braun, M., Christianen, P.C.M., de Geest, M., Hauslage, J., Hilbig, R., Hill, R.J.A., Lebert, M., Medina, F.J., Vagt, N., Ullrich, O., van Loon, J.J.W.A., Hemmersbach, R.: Ground-Based Facilities for Simulation of Microgravity: OrganismSpecific Recommendations for Their Use, and Recommended Terminology. Astrobiology 13, 1-17 (2013). https://doi.org/10.1089/ ast.2012.0876 
Infanger, M., Kossmehl, P., Shakibaei, M., Baatout, S., Witzing, A., Grosse, J., Bauer, J., Cogoli, A., Faramarzi, S., Derradji, H., Neefs, M., Paul, M., Grimm, D.: Induction of three-dimensional assembly and increase in apoptosis of human endothelial cells by simulated microgravity: Impact of vascular endothelial growth factor. Apoptosis. 11, 749-764 (2006)(a). https://doi.org/10.1007/ s10495-006-5697-7

Infanger, M., Kossmehl, P., Shakibaei, M., Bauer, J., Kossmehl-Zorn, S., Cogoli, A., Curcio, F., Oksche, A., Wehland, M., Kreutz, R., Paul, M., Grimm, D.: Simulated weightlessness changes the cytoskeleton and extracellular matrix proteins in papillary thyroid carcinoma cells. Cell Tissue Res. 324, 267-277 (2006)(b). https:// doi.org/10.1007/s00441-005-0142-8

Ivanova, K., Eiermann, P., Tsiockas, W., Hemmersbach, R., Gerzer, R.: Differential Regulation of cGMP Signaling in Human Melanoma Cells at Altered Gravity: Simulated Microgravity DownRegulates Cancer-Related Gene Expression and Motility. Microgravity Sci. Technol. 30, 457-467 (2018). https://doi.org/10.1007/ s12217-018-9611-z

Janmaleki, M., Pachenari, M., Seyedpour, S.M., Shahghadami, R., SanatiNezhad, A.: Impact of Simulated Microgravity on Cytoskeleton and Viscoelastic Properties of Endothelial Cell. Sci. Rep. 6, 1-11 (2016). https://doi.org/10.1038/srep32418

Kang, C.Y., Zou, L., Yuan, M., Wang, Y., Li, T.Z., Zhang, Y., Wang, J.F., Li, Y., Deng, X.W., Liu, C.T.: Impact of simulated microgravity on microvascular endothelial cell apoptosis. Eur. J. Appl. Physiol. 111, 2131-2138 (2011)(a). https://doi.org/10.1007/ s00421-011-1844-0

Kang, C.Y., Zou, L., Yuan, M., Wang, Y., Li, T.Z., Zhang, Y., Wang, J.F., Li, Y., Deng, X.W., Liu, C.T.: Impact of simulated microgravity on microvascular endothelial cell apoptosis. Eur. J. Appl. Physiol. 111, 2131-2138 (2011)(b). https://doi.org/10.1007/ s00421-011-1844-0

Kartalou, M., Essigmann, J.M.: Mechanisms of resistance to cisplatin. Mutat. Res. - Fundam. Mol. Mech. Mutagen. 478, $23-43$ (2001). https://doi.org/10.1016/S0027-5107(01)00141-5

Kim, Y.J., Jeong, A.J., Kim, M., Lee, C., Ye, S.K., Kim, S.: Timeaveraged simulated microgravity (taSMG) inhibits proliferation of lymphoma cells, L-540 and HDLM-2, using a 3D clinostat. Biomed. Eng. Online. 16, 1-12 (2017). https://doi.org/10.1186/ s12938-017-0337-8

Kohn, F.P.M., Hauslage, J.: The gravity dependence of pharmacodynamics: the integration of lidocaine into membranes in microgravity. npj Microgravity. 5, (2019). https://doi.org/10.1038/ s41526-019-0064-5

Kopp, S., Krüger, M., Wehland, M., Bauer, J., Dittrich, A., Infanger, M., Grimm, D.: Growing Tissues in Space. Front. Physiol. 9, (2018). https://doi.org/10.3389/conf.fphys.2018.26.00014

Kossmehl, P., Shakibaei, M., Cogoli, A., Infanger, M., Curcio, F., Schönberger, J., Eilles, C., Bauer, J., Pickenhahn, H., SchulzeTanzil, G., Paul, M., Grimm, D.: Weightlessness induced apoptosis in normal thyroid cells and papillary thyroid carcinoma cells via extrinsic and intrinsic pathways. Endocrinology 144, 4172-4179 (2003). https://doi.org/10.1210/en.2002-0171

Krause, L., Braun, M., Hauslage, J., Hemmersbach, R.: Analysis of Statoliths Displacement in Chara Rhizoids for Validating the Microgravity-Simulation Quality of Clinorotation Modes. Microgravity Sci. Technol. 30, 229-236 (2018). https://doi.org/10.1007/ s12217-017-9580-7

Kyu-Ho Han, E., Gehrke, L., Tahir, S.K., Credo, R.B., Cherian, S.P., Sham, H., Rosenberg, S.H., Ng, S.C.: Modulation of drug resistance by $\alpha$-tubulin in paclitaxel-resistant human lung cancer cell lines. Eur. J. Cancer. 36, 1565-1571 (2000). https://doi.org/10. 1016/S0959-8049(00)00145-3

Lambert, C.A., Lapière, C.M., Nusgens, B. V.: Biology of Adherent Cells in Microgravity. (2007)
Lei, X., Cao, Y., Zhang, Y., Qian, J., Zhao, Q., Liu, F., Zhang, T., Zhou, J., Gu, Y., Xia, G., Duan, E.: Effect of microgravity on proliferation and differentiation of embryonic stem cells in an automated culturing system during the TZ-1 space mission. Cell Prolif. 1-10 (2018). https://doi.org/10.1111/cpr.12466

Li, C.F., Sun, J.X., Gao, Y., Shi, F., Pan, Y.K., Wang, Y.C., Sun, X.Q.: Clinorotation-induced autophagy via HDM2-p53-mTOR pathway enhances cell migration in vascular endothelial cells. Cell Death Dis. 9, (2018). https://doi.org/10.1038/s41419-017-0185-2

Li, J., Zhang, S., Chen, J., Du, T., Wang, Y., Wang, Z.: Modeled microgravity causes changes in the cytoskeleton and focal adhesions, and decreases in migration in malignant human MCF-7 cells. Protoplasma 238, 23-33 (2009). https://doi.org/10.1007/ s00709-009-0068-1

Ma, X., Pietsch, J., Wehland, M., Schulz, H., Saar, K., Hübner, N., Bauer, J., Braun, M., Schwarzwälder, A., Segerer, J., Birlem, M., Horn, A., Hemmersbach, R., Waßer, K., Grosse, J., Infanger, M., Grimm, D.: Differential gene expression profile and altered cytokine secretion of thyroid cancer cells in space. FASEB J. 28, 813-835 (2014). https://doi.org/10.1096/fj.13-243287

Nadin, S.B., Vargas-Roig, L.M., Ciocca, D.R.: A Silver Staining Method for Single-cell Gel Assay. J. Histochem. Cytochem. 49, 1183-1186 (2001). https://doi.org/10.1177/002215540104900912

Nassef, M.Z., Kopp, S., Melnik, D., Corydon, T.J., Sahana, J., Krüger, M., Wehland, M., Bauer, T.J., Liemersdorf, C., Hemmersbach, R., Infanger, M., Grimm, D.: Short-term microgravity influences cell adhesion in human breast cancer cells. Int. J. Mol. Sci. 20, (2019). https://doi.org/10.3390/ijms20225730

Pei, P.G., Pasquier, E., Kavallaris, M.: Class III $\beta$-tubulin mediates sensitivity to chemotherapeutic drugs in non-small cell lung cancer. Cancer Res. 67, 9356-9363 (2007). https://doi.org/10.1158/ 0008-5472.CAN-07-0509

Piepmeier, E.H., Kalns, J.E., McIntyre, K.M., Lewis, M.L.: Prolonged weightlessness affects promyelocytic multidrug resistance. Exp. Cell Res. 237, 410-418 (1997). https://doi.org/10.1006/excr.1997. 3813

Pisanu, M.E., Noto, A., De Vitis, C., Masiello, M.G., Coluccia, P., Proietti, S., Giovagnoli, M.R., Ricci, A., Giarnieri, E., Cucina, A., Ciliberto, G., Bizzarri, M., Mancini, R.: Lung Cancer Stem Cell Lose Their Stemness Default State after Exposure to Microgravity. Biomed Res. Int. 2014, (2014). https://doi.org/10.1155/ 2014/470253

Rudimov, E.G., Buravkova, L.B.: Gravisensitivity of endothelial cells: the role of cytoskeleton and adhesion molecules. Hum. Physiol. 42, 687-693 (2016). https://doi.org/10.1134/S0362119716060177

Shen, D.W., Pouliot, L.M., Hall, M.D., Gottesman, M.M.: Cisplatin resistance: A cellular self-defense mechanism resulting from multiple epigenetic and genetic changes. Pharmacol. Rev. 64, 706-721 (2012). https://doi.org/10.1124/pr.111.005637

Sokolovskaya, A.A., Ignashkova, T.I., Bochenkova, A.V., Moskovtsev, A.A., Baranov, V.M., Kubatiev, A.A.: Effects of simulated microgravity on cell cycle in human endothelial cells. Acta Astronaut. 99, 16-23 (2014). https://doi.org/10.1016/j.actaastro.2014.01.032

Stewart, D.J.: Mechanisms of resistance to cisplatin and carboplatin. Crit. Rev. Oncol. Hematol. 63, 12-31 (2007). https://doi.org/10. 1016/j.critrevonc.2007.02.001

Sundaresan, A., Risin, D., Pellis, N.R.: Cell Growth in Microgravity Keywords. 303-322 (2004)

Svejgaard, B., Wehland, M., Ma, X., Kopp, S., Sahana, J., Warnke, E., Aleshcheva, G., Hemmersbach, R., Hauslage, J., Grosse, J., Bauer, J., Corydon, T.J., Islam, T., Infanger, M., Grimm, D.: Common effects on cancer cells exerted by a random positioning machine and a 2D clinostat. PLoS One. 10, (2015). https://doi.org/10.1371/ journal.pone.0135157

Vidyasekar, P., Shyamsunder, P., Arun, R., Santhakumar, R., Kapadia, N.K., Kumar, R., Verma, R.S.: Genome wide expression profiling 
of cancer cell lines cultured in microgravity reveals significant dysregulation of cell cycle and MicroRNA gene networks. PLoS ONE 10, 1-20 (2015). https://doi.org/10.1371/journal.pone.0135958

Wang, Y.C., Lu, D.Y., Shi, F., Zhang, S., Yang, C.B., Wang, B., Cao, X.S., Du, T.Y., Gao, Y., Zhao, J.D., Sun, X.Q.: Clinorotation enhances autophagy in vascular endothelial cells. Biochem. Cell Biol. Biol. Cell. 91, 309-314 (2013). https://doi.org/10.1139/ bcb-2013-0029

Wehland, M., Aleshcheva, G., Schulz, H., Saar, K., Hübner, N., Hemmersbach, R., Braun, M., Ma, X., Frett, T., Warnke, E., Riwaldt, S., Pietsch, J., Corydon, T.J., Infanger, M., Grimm, D.: Differential gene expression of human chondrocytes cultured under short-term altered gravity conditions during parabolic flight maneuvers. Cell Commun. Signal. 13, 1-13 (2015). https://doi. org/10.1186/s12964-015-0095-9

Wuest, S.L., Richard, S., Kopp, S., Grimm, D., Egli, M.: Simulated microgravity: Critical review on the use of random positioning machines for mammalian cell culture. Biomed Res. Int. 2015, (2015). https://doi.org/10.1155/2015/971474

Wuest, S.L., Stern, P., Casartelli, E., Egli, M.: Fluid Dynamics Appearing during Simulated Microgravity Using Random Positioning Machines. PLoS ONE 12, e0170826 (2017). https://doi.org/10. 1371/journal.pone.0170826

Xu, D., Guo, Y.B., Zhang, M., Sun, Y.Q.: The subsequent biological effects of simulated microgravity on endothelial cell growth in HUVECs. Chinese J. Traumatol. - English Ed. 21, 229-237 (2018). https://doi.org/10.1016/j.cjtee.2018.04.004

Zhu, M., Jin, X., Wu, B., Nie, J., Li, Y.: Effects of simulated weightlessness on cellular morphology and biological characteristics of cell lines SGC-7901 and HFE-145. Genet. Mol. Res. 13, 60606069 (2014). https://doi.org/10.4238/2014.August.7.20

Publisher's Note Springer Nature remains neutral with regard to jurisdictional claims in published maps and institutional affiliations. 